\title{
Quality of Agroecological Matrix in a Tropical Montane Landscape: Ants in Coffee Plantations in Southern Mexico
}

\author{
IVETTE PERFECTO* AND JOHN VANDERMEER $†$ \\ *School of Natural Resources and Environment, University of Michigan, Ann Arbor, MI 48109, U.S.A., \\ email perfecto@umich.edu \\ †Department of Biology, University of Michigan, Ann Arbor, MI 48109, U.S.A.
}

\begin{abstract}
Conservation efforts in fragmented landscapes frequently focus on characteristics of the babitat fragments. We propose that the matrix within which habitat fragments occur is of equal importance and focus on quality of the matrix as an interesting variable. We studied ground-foraging ants in isolated montane forest fragments in the matrix of coffee agroecosystems of southwestern Chiapas, Mexico. We sampled the ants, with tuna fish as bait, in plots at various distances from a forest fragment (2-750 $\mathrm{m}$ ) on two farms, one an organic farm with considerable shade, the other a conventional farm with only spotty shade. Each plot contained a grid of $49(7 \times 7)$ or $100(10 \times 10)$ baits. The species richness of ground-foraging ants was not significantly different between the forest fragment and the bigh-quality matrix, but it was significantly lower in the low-quality matrix than in the forest. Furthermore, species richness decreased with distance from the forest fragment in both matrix types. However, the rate of decrease in species richness was greater in the conventional farm (poor-quality matrix) than in the organic farm (bigh-quality matrix), suggesting that the quality of the agricultural matrix is important for the conservation of ant diversity.
\end{abstract}

Calidad de la Matriz Agroecológica en un Paisaje Montañoso Tropical: Hormigas en Plantaciones de Café en el Sur de México

Resumen: Los esfuerzos de conservación en paisajes fragmentados frecuentemente enfocan las características de los fragmentos de hábitat. Proponemos que la matriz en la cual ocurren fragmentos de hábitat es de igual importancia y enfocamos la calidad de la matriz como una variable interesante. Estudiamos hormigas del suelo en fragmentos aislados de bosque montano en la matriz de agrosistemas de café en el sudoeste de Chiapas, México. Muestreamos hormigas, con aceite de atún como atractante, en parcelas a varias distancias (de 2 a $750 \mathrm{~m}$ ) de un fragmento de bosque en dos baciendas, uno orgánico con sombra considerable, el otro convencional con sombra escasa. Cada parcela contenía una red de 49 ( 7 X 7) o 100 (10 X 10) cebos. La riqueza de especies de bormiga no fue significativamente diferente entre los fragmentos de bosque y la matriz de alta calidad. Pero fue significativamente menor en la matriz de baja calidad comparada con el bosque. Mas aún, la riqueza de especies disminuyó a mayor distancia del fragmento de bosque en ambos tipos de matriz. Sin embargo, la tasa de disminvaón de la riqueza de especies fue mayor en la bacienda convencional (matriz de baja calidad) que en la hacienda orgánico (matriz de alta calidad). Lo que sugiere que la calidad de la matriz agrícola es importante para la conservación de la diversidad de hormigas. 


\section{Introduction}

Conservation biologists are increasingly aware that the matrix within which forest fragments exist may be as important for conservation as the forest fragments themselves (Laurance 1991; Bierregaard et al. 1992; Franklin 1993; Weins et al. 1995; Gustafson \& Gardner 1996; Jules 1997; Vandermeer \& Perfecto 1997). Theoretically, the matrix may affect the rate of migration of organisms among forest patches and thus influence extinction rates on a regional level, or the matrix may create conditions that alter extinction rates within the forest fragments themselves (Gustafson \& Gardner 1996; Cantrell et al. 1998). Empirically, examples exist in which the quality of the matrix has an effect on the existence of species in forest fragments. For example, the majority of frogs in the Manaus area of Brazil are maintained in forest fragments because they appear to use the surrounding matrix (Tocher et al. 1997). Also, Swedish Pea Hens (Bonasia bonasia) more commonly occupy forest fragments when those fragments are located within a semiforested matrix than when they are located in a matrix of conventional agriculture (Aberg et al. 1995).

In the past, conservation in tropical climates was concentrated on preserved areas such as national parks and set-aside nature areas. More recently it has been emphasized that the majority of contemporary tropical landscapes are in a state of extensive forest fragmentation (Laurance \& Bierregaard 1997). Deforestation has been severe throughout the tropics, yet what is left is not a homogeneous landscape. Rather, small patches of forest remain. These small patches may not be suitable for megafauna, but could be critical to the conservation of less evident organisms such as insects, other invertebrates, and lower plants. Although it is desirable to develop programs to encourage the preservation of these many fragments, an additional problem is management of the matrix in which they occur. This effectively means management of the agroecosystems that almost inevitably occupy the area between forest fragments. Attention to the agroecosystem that makes up the majority of the matrix may be key to conservation at the landscape level (Vandermeer \& Perfecto 1997).

In many tropical montane areas the matrix is occupied by coffee plantations. Coffee is the second most traded commodity in the world (second to petroleum) and represents the majority of mid-elevation agroecosystem land in northern Latin America (Perfecto et al. 1996). The traditional coffee plantation is an agroforestry system with many shade and fruit trees interplanted with the coffee bushes. An even more forest-like system can be found in Mesoamerica in which the original forest cover has been maintained and coffee bushes have been planted in the cleared understory, the so-called "rustic coffee" system (Moguel \& Toledo 1999). At the other extreme is the "sun coffee" system, which has been promoted by some international agencies, in which most or all shade trees are removed and the use of chemical fertilizers and biocides is common (Perfecto et al. 1996; Rice 1997). This transition from the traditional to the modern technified system has recently drawn much attention because of its implications for biodiversity conservation (Perfecto et al. 1996; Moguel \& Toledo 1999). In the context of the matrix within which forest fragments are located, the coffee system thus represents what could be variable matrix qualities, from the expected high-quality rustic system to the expected low-quality sun system (Perfecto \& Vandermeer 1994; Perfecto \& Snelling 1995; Greenberg et al 1997a 1997b; Perfecto et al. 1997). We sought to determine whether different levels of coffee intensification-rustic coffee being the least intense and sun coffee being the most intense-represent different matrix qualities with respect to a selected bioindicator group.

We focused on ants (Hymenoptera: Formicidae), organisms that frequently have been cited as important for conservation and useful as bioindicators (Majer 1983; Andersen 1990; Read 1996; Agosti et al. 2000). Because insects form the most species-diverse animal taxon in the world and ants form the bulk of insect biomass in most tropical regions (Hölldobler \& Wilson 1990), their importance is evident. In this context, the "quality" of the matrix takes on a particular meaning. Focusing on the eventual need for interfragment migration, we considered a high-quality matrix to be one in which the barriers to migration are small. The matrix may not provide a source habitat for particular ant species (i.e., the species may not be able to persist indefinitely there), but it may not be a perfect sink either (i.e., a propagule landing there may not perish immediately). We see the process of interfragment migration in two categories, direct and indirect migration. The principle migratory event for ants is the nuptial flight. Flying ants may be carried long distances by the wind, but they mostly fly short distances to locate a nest site and establish a new colony (Hölldobler \& Wilson 1990).

Direct migration occurs when a queen originating from a forest fragment is fertilized, flies, and lands on another forest fragment. The likelihood of this occurring depends on the size and spatial separation of forest fragments. Indirect migration occurs when a fertilized queen establishes a colony in the matrix; the colony survives in the matrix at least until it reaches maturity and produces new queens that will mate and disperse to find new nesting sites. Some of the fertilized queens will establish new colonies in the matrix to repeat the process. Eventually one of the future descendents of the original queen establishes a colony in a new fragment. It is evident that the quality of the matrix is especially important for indirect migration. Even if the matrix is not of sufficiently high quality to maintain the population of a particular species in perpetuity (a source habitat), it may 
be sufficiently benign such that populations may become temporarily established, enabling indirect migration to occur.

Given the above, we expect that (1) a higher-quality matrix will contain more species than a lower-quality one; (2) there will be lower species richness farther from a forest fragment; and 3) this decrease will be more evident in a lower-quality matrix. To test these hypotheses, we sampled ants at a variety of distances from a small forest preserve that separates two coffee farms, one we assumed to be a high-quality matrix and the other a low-quality matrix.

\section{Methods}

We conducted our study during June and July 1998 and 1999 on two farms in southern Mexico in the Soconusco region of Chiapas, located on a mountain mass just north of the Tacaná volcano near the border with Guatemala. One farm, Irlanda (lat. $15^{\circ} 10^{\prime} \mathrm{N}$, long. $92^{\circ} 20^{\prime} \mathrm{W}$ ), is a traditional polyculture in which over 200 species of trees provide shade for organically grown coffee (no use of agrochemicals). The other farm, Hamburgo (lat. $15^{\circ} 10^{\prime} \mathrm{N}$, long. $92^{\circ} 19^{\prime} \mathrm{W}$ ), is more technified, has far less shade, and is managed with agrochemicals. Managers routinely use Thiodan (an organophosphate) for control of the coffee berry borer (Hypothenemus hampei), although for the 2 years prior to our study its application was unnecessary. Herbicides and fungicides are also used routinely.

Irlanda does not represent an extreme on the intensification gradient in that its shade cover is pruned and mostly planted, as opposed to the natural-forest cover found in the classic rustic coffee farms. Although there are many tree species on the farm, the majority (about $60 \%$ ) are three species of Inga. Nevertheless, from afar the farm appears almost as a forest (Fig. 1a). Under the standard system of classifying Mexican coffee plantations (Moguel \& Toledo 1999), it would be classified as traditional polyculture. Hamburgo is not an extreme sun-coffee system; rather, it is a patchwork of moderately shaded and full-sun coffee (Fig. 1b). Under the standard classification system, Hamburgo would be considered a patchwork of technified shaded and sun coffee (Moguel \& Toledo 1999).

Between the two farms is a small biological reserve, La Montañita, of typical montane forest with large trees (many Sloanea sp.), patches of second growth representing the aftermath of local landslides, large-diameter lianas, a well-developed understory with at least four species of palms in the genus Chamaedorea, an evident scandant shrub in the genus Asplundia, and abundant orchid, bromeliad and aroid epiphytes, including a largeleafed Anthurium. Its extent is limited (about 15 ha, approximately $1300 \mathrm{~m}$ long, and ranging from 50 to $400 \mathrm{~m}$

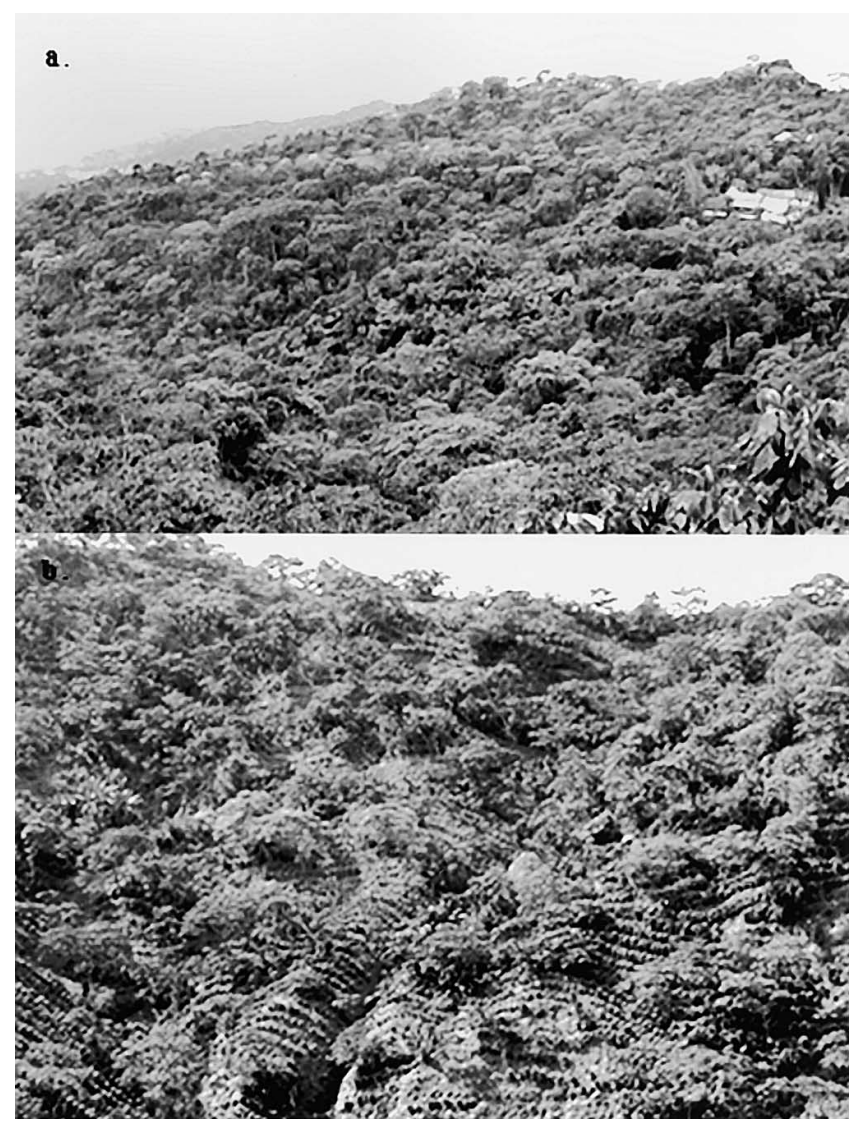

Figure 1. Two coffee farms: (a) Irlanda, an organic, shaded coffee farm, and (b) Hamburgo, a conventional sun system with scattered shade.

wide), and it apparently has never been cut, partly because it is on land too steep for agriculture and partly because it has been purposefully retained for watershed protection. On Irlanda, another biological preserve is located approximately $1 \mathrm{~km}$ southwest of La Montañita.

In addition to the two farms in our study, to the south is another organic coffee farm, Santa Anita, and to the northwest is a highly technified conventional coffee farm, San Cristobal. Forest fragments are scattered throughout the region (Fig. 2).

We defined ground-foraging ants as those species attracted to tuna-fish baits placed on the ground. As with any study, the sampling method defines the community studied. A grid of either 49 baits $(7 \times 7)$ or 100 baits $(10 \times$ 10), with each bait separated by $2 \mathrm{~m}$, was placed on the ground at each sampling location. All but two of the sites had 49 baits. The two 100-bait sites were established to compare extrapolations of species sample curves from the 49-bait sites. Because there were no significant differences between comparing extrapolations from 100bait samples and comparing extrapolations from 49-bait samples, this comparison is not discussed further. Baits were set and then checked after 45 minutes. All ants were 

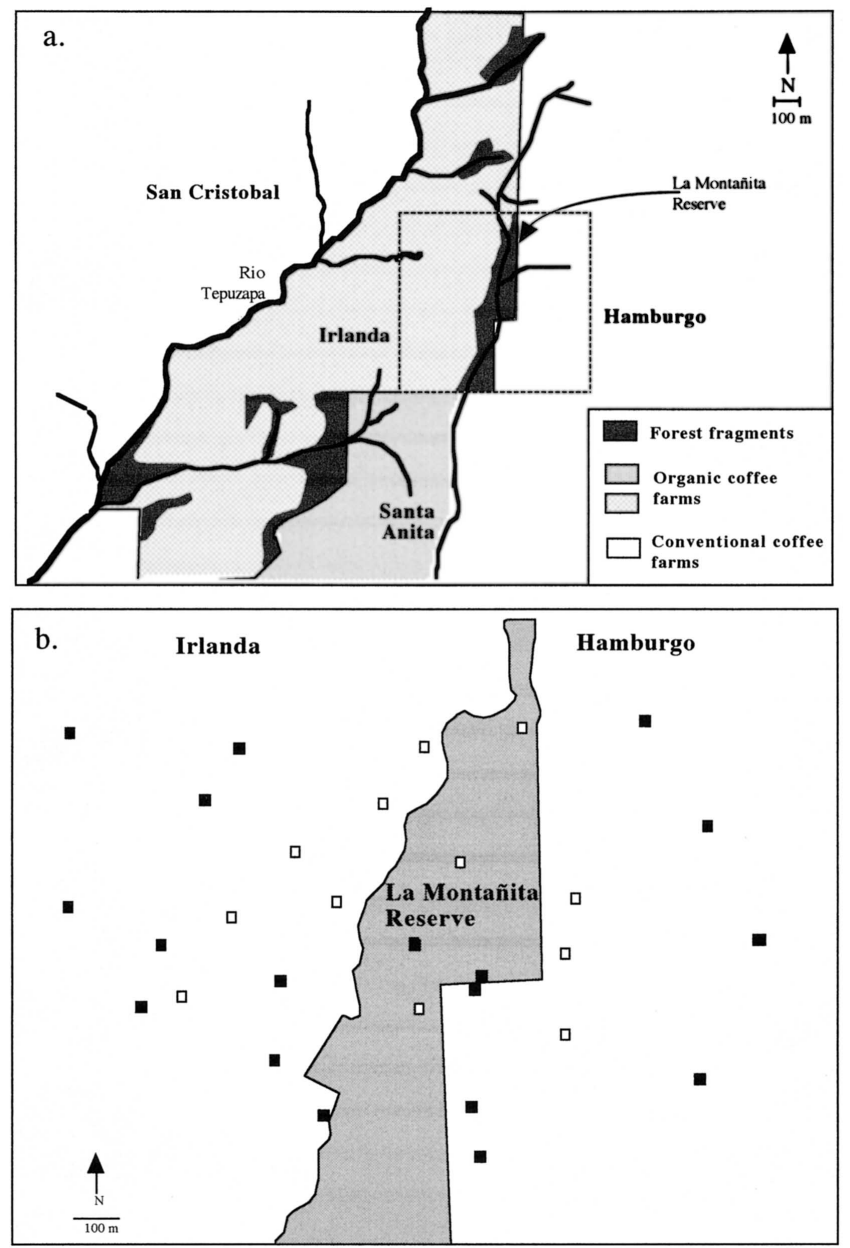

Figure 2. The study site in Chiapas, Mexico: (a) patchwork of forest fragments on the Irlanda farm and (b) location of sample sites on the Irlanda and Hamburgo farms (expanded from dashed square in a). Black squares are sample sites from 1999, open squares are from 1998.

identified to morphospecies, and voucher specimens were collected for each new species encountered. Morphospecies identifications were based on size, morphology, color, and behavior. All collections were identified to genus in the laboratory.

Neither 49 nor 100 baits necessarily provide good estimates of the entire biodiversity of an area, but the pattern of accumulation of species can be used to estimate the asymptotic species richness through a variety of methods (Colwell \& Coddington 1994). We used the program CAPTURE (White et al. 1978; also available at http://www.mbr.nbs.gov:80/specrich2.html), which is based on the idea that species are marked in one sample and "recaptured" in another (Burnham \& Overton 1979). The program CAPTURE provided estimates of both the number of species at the sampling site and the standard error of the estimate. We generated species-accumula- tion curves by resampling baits on a random basis to estimate the number of species for a given number of baits, thus generating a curve of the number of species as a function of the number of baits (Stout \& Vandermeer 1975). The total number of species estimated by CAPTURE was visually compared with the species-accumulation curves. In all but three cases the estimated value of $S$ (species richness, or total number of species) was similar to what would have been estimated from a visual extrapolation of the species-sample curves. In the three other cases, estimated $S$ was orders of magnitude different from a reasonable extrapolation. (Visual extrapolations provided estimates of 6-15 species, whereas the estimates from CAPTURE were all over 50.) In these three cases we fit the curves to the Mechaelis Menten function, $S=a B /(b+B)$, where $S$ is number of species, $B$ is number of baits, and $a$ and $b$ are constants. The constant $a$ is the maximum number of species at the sampling site (i.e., the limiting value of $S$ as $B$ approaches infinity), and $b$ is a measure of the rate at which species accumulate with additional baits. Our estimate of the number of species at a sampling site for these three cases was thus taken as the parameter $a$. We had no estimate of the standard error for those three sites.

Five sampling sites were set within the reserve as baseline data. Ten sites were set at various distances from the reserve in Hamburgo and fifteen sites in Irlanda. More sites were established in Irlanda because we were concerned that the larger species diversity there would make it more difficult to see a pattern. We sampled fewer sites in the forest because we believed the forest was a more homogeneous habitat. The locations of all 30 sites are shown in Fig. 2. We established the location of all points with a global positioning system (GPS), with an estimated accuracy of $15 \mathrm{~m}$ and corroborated them when possible with reference to a map. Actual distances were difficult to determine because of the rugged topography. For example, two of the points in Hamburgo were estimated with a GPS to be 50 and 75 $\mathrm{m}$ from the reserve. But we estimated that a ground measurement would have yielded something more on the order of 80 and $105 \mathrm{~m}$ because of the steep topography. Which measurement would be most important to ants is impossible to discern. For purposes of this study, the distances we estimated were "as the crow flies."

Sampling protocols were identical in 1998 and 1999, but the choice of sampling locations was slightly different between the 2 years. In 1998, random positions were located relatively near the forest preserve and relatively far from the forest preserve in Irlanda, but only relatively near to the forest preserve in Hamburgo. This was done because we initially thought the effect of distance from forest would be relevant only in Irlanda. Sites were randomly selected after stratification of near and far, but because points were chosen at random, they 
sometimes fell on sites that were not representative of the farm as a whole. For this reason, in 1999 we chose points haphazardly, with the intention of sampling a diversity of distances from the forest and areas typical or representative of ideal types. Both farms are a mosaic of small patches of natural vegetation (usually in deep ravines and gullies), shaded coffee, landslides, and open coffee. The majority of Hamburgo is lightly shaded or in full sun, whereas the majority of Irlanda is under the shade of a variety of species of trees (Fig. 1), with only rare patches of coffee in full sun, usually because of a recently fallen tree or a landslide. We attempted to avoid particular sites that were unusual for the farm in question. In Hamburgo, we avoided sites that were especially shady because we hoped to capture the habitat characteristics of a lightly shaded or full-sun plantation. In Irlanda, we avoided sites that were opened recently by a landslide or treefall so that we could capture the habitat characteristics of a traditional polyculture plantation. The data from all sites were handled in the same way.

Site number 1 in Hamburgo was placed such that its edge was about $1 \mathrm{~m}$ from the edge of the forest. It was an unusual site and deserves a separate analysis. While collecting the data, we found that the rows of bait nearest the forest contained many more species than rows farther from the forest. To examine this fine-scale difference, we separated the data at this site into pairs of rows - the first pair nearest the forest and the last pair furthest from the forest-and analyzed each pair of rows separately. Species-accumulation curves were thus performed for 20 baits at at time (two rows of 10 baits each) for five distances from the forest $(2,6,10,14$, and $18 \mathrm{~m})$.

\section{Results}

The estimated number of species of ants per site for the forest ranged from 14 to 43. For site 1 in Hamburgo there was a clear decrease in number of species with increasing distance from the forest, from the first pair to the fifth pair, respectively (Fig. 3). The difference between the first pair of rows $(2 \mathrm{~m})$ and the last pair $(18 \mathrm{~m})$ was only $16 \mathrm{~m}$. The dramatic difference between "near the forest" and $18 \mathrm{~m}$ from the forest required that this site be treated differently from the rest. Thus, we estimated the number of species from the program CAPTURE using each pair of rows.

There was a statistically significant regression of number of species versus distance from forest for the Irlanda site $\left(r^{2}=0.287\right.$; Table 1 ; Fig. 4$)$. The regression of species versus distance from forest was not significant for the Hamburgo site, but the dramatic decline from the edge of the forest even at very small distances (Fig. 3) suggests that the expected pattern was nevertheless extant.

Based on results from a standard $t$ test, there was an obvious and statistically significant difference between the two farms $(p=0.00001)$ and between the poorquality matrix (Hamburgo) and the forest ( $p=0.027$ ). The difference between the forest and the high-quality matrix (Irlanda) was not significant $(p=0.178)$. Al-

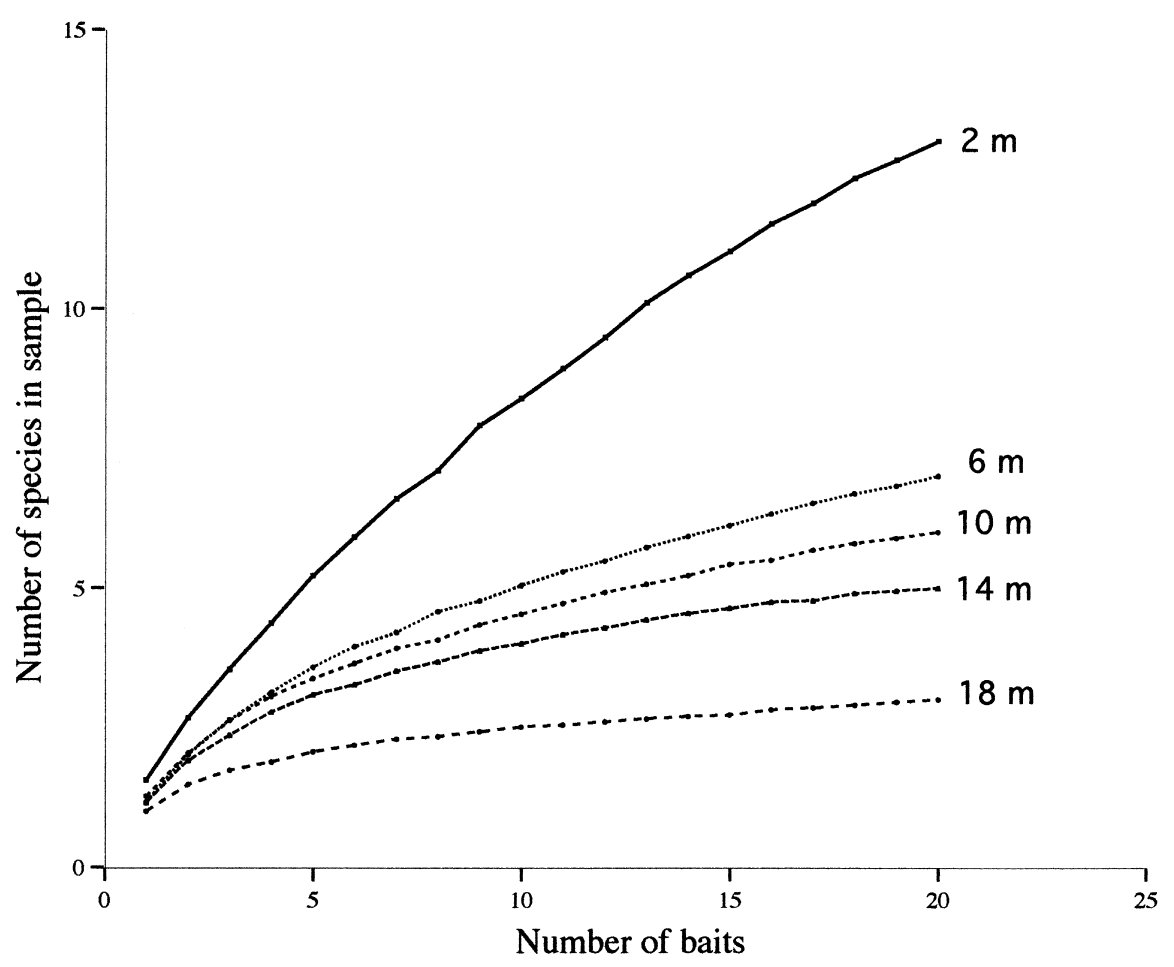

Figure 3. Species-accumulation curves for the Hamburgo site adjacent to the forest. Each accumulation curve is for two rows of bait, parallel to the forest edge, at the distance from the forest indicated on the figure (labels on the curves indicate bow far the midpoint between the two rows was located from the edge of the forest). Each accumulation curve is thus based on 20 baits, 10 in each row. 
Table 1. Analysis of variance for the regression of number of species versus distance from forest for Irlanda coffee plantation sites.

\begin{tabular}{lrrrrc} 
& $d f$ & \multicolumn{1}{c}{$S S$} & \multicolumn{1}{c}{$M S$} & $\mathrm{~F}$ & $\mathrm{p}$ \\
\hline Regression & 1 & 133.13 & 133.13 & 5.24 & 0.04 \\
Residual & 13 & 330.46 & 25.42 & & \\
Total & 14 & 463.60 & & & \\
\hline
\end{tabular}

though the high-quality matrix had fewer species than the forest on average, that difference was not significant.

\section{Discussion}

There was a clear difference between the two farms in terms of the number of species of ground-foraging ants. The traditional organic polyculture farm contained almost as many ant species, on average, as the forest itself. The conventional technified farm contained far fewer. In general one would expect to find about 23 species in the forest, about 16 in the traditional polyculture, and only about 7 in the technified system, based on the data report here (Fig. 4). Our results are consistent with results we report elsewhere for ground-foraging ants in Costa Rica (Perfecto \& Vandermeer 1994; Perfecto \& Snelling 1995).

Our hypothesis that there should be a decreasing number of species with distance from forest was not statistically supported in Hamburgo, except for the very near effect. The distance hypothesis was supported (the highquality matrix of) in Irlanda (Fig. 4). It would thus seem that both farms were source habitats (i.e., populations can survive there in perpetuity) for some species but sink habitats for others. This is especially true for Hamburgo. The traditional polyculture (Irlanda) seemed to be only slightly different than the forest as far as groundforaging ants are concerned, contrary to the situation in the conventional system (Hamburgo).

On the other hand, at a micro scale the effect of distance from forest was dramatic in Hamburgo (Fig. 3). It is highly unlikely that this effect results from founding queens; rather, it is likely the effect of forest species moving their nests from the forest to the forest edge. Alternatively, some colonies, having been founded in the agricultural matrix, may move to the forest edge where microclimatic conditions may be more favorable. At any rate, the pattern at this fine scale is likely the result of small-scale movements rather than large-scale dispersion. This effect was not seen in the Irlanda sites directly adjacent to the forest, partly because from the ant's perspective there is no edge (i.e., traditional polyculture is almost the same as forest). Regardless of the mechanisms, the dramatic decline at this scale is testament to the unsuitability of the habitat on the conventional farm for many forest species of ground-foraging ants.

Certain aspects of the natural history of individual species are relevant to the interpretation of our results. One ant species, Pheidole sp., is overwhelmingly abundant at all sites. Typically, $30-50 \%$ of baits at any site were occu-

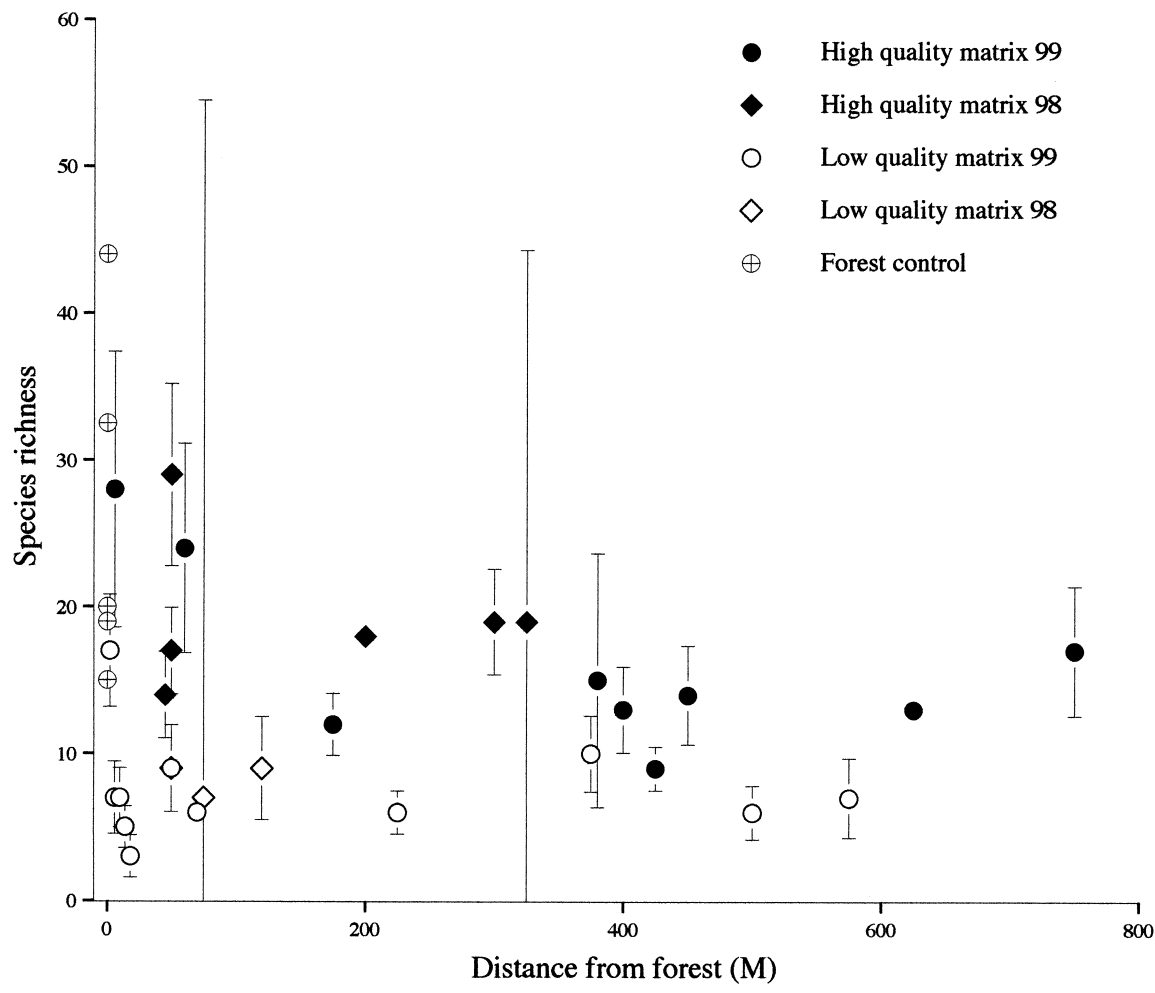

Figure 4. Species richness (as estimated by the program CAPTURE, with exceptions as noted in the text) for 1998 and 1999 as a function of distance from forest. 
pied by this species. There was no evidence that Pheidole sp. distinguished among the three habitats. It is a small ant but physically aggressive and was frequently seen attacking and overcoming other, larger ant species. Two other species were common in both coffee habitats but were rarely encountered in the forest: Gnaptogenys sulcata and Solenopsis geminata. The latter is notorious for its physically aggressive behavior and occupies sites not suitable for other species in other situations (Perfecto 1991, 1994), but its obvious presence in disturbed habitat is not evidence that it actually excludes other species. In Costa Rican sun-coffee plantations, for example, the seemingly less aggressive Pheidole radoszkowskii appears to outcompete $S$. geminata because of the former's ability to rapidly discover resources (Perfecto 1994). Consequently, the well-known observation that $S$. geminata occurs where other species are rare may not be a consequence of $S$. geminata being an aggressive competitor, but rather of its ability to nest where other species cannot (Perfecto 1994). Gnaptogenys sulcata is a small ant in the subfamily Ponerinae that recruits more actively than normal for a ponerine. It is highly correlated with the presence of the predominant Pheidole sp. at the two farm sites (personal observations), although it was never encountered in the forest in our study (in a parallel study it was encountered rarely in the forest [I. Armbrecht, personal communication]). Thus, we doubt that either G. sulcata or S. geminata exerts a direct effect that causes other species to disappear. Rather, their abundance may be more a fact of the other species not being able to survive well in these matrix habitats. Although it could be that the presence of these two species has a major effect on the quality of the matrix, our study cannot disentangle the potential causal pathways that might be involved.

In this study we used species richness as an index of matrix quality. It might be argued that the actual identity of the species involved is more important than the absolute value of species richness. For example, if there are many "matrix specialists" involved, it is not of much interest that the matrix contains many or few species. In our study, however, there were no species that did not occur in the forest, although two of the common species in the matrices were rare in the forest. Thus, the ant communities in the two matrices probably represented the same communities, albeit highly modified, that existed in the forest, and the species richness likely reflects the quality of the matrix.

The cause of the difference between the two farm types is not known. It appears that the general physical features of the habitat are more conducive to ants in the organic traditional polyculture, but this is only speculation. Another possibility is the effect of army ants. Casual observations made in 1999 suggest that army ants are more abundant in the traditional polyculture than in the conventional system, something that has been ob- served in Panama (I.P., personal observation). The disturbance caused by army ants is an important factor in maintaining species diversity in a tropical rainforest in Panama (Franks \& Bossert 1983). It may be that the "disturbance" caused by army ants is "opening" spaces for newly fertilized queens to become established in the traditional organic polyculture system. That is, as queens fly and seek nesting sites, the mosaic of empty habitats left by army ants in the organic polycultural system may be more conducive for new nests than the fully occupied habitats of the conventional system.

An additional difference between the two sites is the abundance of trees in the genus Inga. Although both farms have these trees, they are far more abundant in Irlanda than in Hamburgo. Because all the species of Inga in this study contain extrafloral nectaries, it is likely that the effect on the general ant community is large. Few species in the ground-foraging ant community forage in the trees, however, and only three species of arboreal ants were found on the bait (Azteca sp., Crematogaster sp., and Pseudomyrmex sp.), and those only rarely. It thus seems unlikely that the presence of extrafloral nectaries in the Inga trees would have had much of an influence on our results.

The context of these results is related to the question of corridors between habitat fragments (Hansson 1991; Hobbs 1992; Beier \& Noss 1998). The basic dynamics are similar in that the corridor is intended to lower rates of extinction in fragments, through the so-called rescue effect (Brown \& Kodric-Brown 1977; Hanski 1985, $1991)$, or to repopulate fragments that have already experienced extinction events (Levins 1969). A high-quality matrix could do the same thing. The basic difference between the corridor idea and the matrix is that, within the context of the corridor concept, it is automatically assumed that the matrix is of such extremely low quality that it can effectively be thought of as a complete sink habitat. That is, any organism entering the matrix is doomed. Thus, the corridor is thought to provide a passage from fragment to fragment through a completely hostile matrix. Although a great deal of theoretical and empirical attention has been accorded the idea of biological corridors, the debate on whether they are effective has not been resolved (Noss 1987; Simberloff \& Cox 1987; Harris \& Scheck 1991; Soulé \& Gilpin, 1991; Crome 1997).

Placing the focus on the matrix is an alternative strategy for dealing with habitat fragmentation. Rather than attempting to promote corridors of high-quality habitat-usually tacitly assumed to be necessarily the same as the fragment habitat itself-the negative aspects usually cited for corridors are largely eliminated when the question is framed in terms of matrix quality. Although the matrix may be formally a sink for most populations of concern, if it provides for sufficient survivorship to ensure travel from fragment to fragment, that is all that 
is required. Although a high-quality matrix may be difficult to construct, perhaps the time and energy (and funds) necessary to connect fragments with habitat-perfect, narrow corridors could sometimes be better spent on efforts to improve the quality of the matrix in which the fragments are located. Which strategy makes more sense depends both on the ecology of the organisms in question and a host of sociopolitical questions that conservation biologists frequently hesitate to confront.

\section{Acknowledgments}

We thank Colegio de la Frontera Sur (ECOSUR) in Tapachula, Chiapas, Mexico, for use of their facilities, especially the Laboratory of Arthropod Ecoethology headed by G. Ibarra-Núñez. We thank A. Garcia-Ballinas for identification of some of the ant species. Special thanks are due to W. Peters, owner of the farm called Finca Irlanda, for his gracious hospitality during the course of the study. This work was partially funded by grant number DEB 9981526 to I.P. from the National Science Foundation.

\section{Literature Cited}

Aberg, J., G. Jansson, J. E. Swenson, and P. Angelstam. 1995. The effect of matrix on the occurrence of hazel grouse (Bonasia bonasia) in isolated habitat fragments. Oecologia 103:265-269.

Agosti, D., J. D. Majer, L. E. Tennant de Alonso, and E. Schultz, editors. 2000. Measuring and monitoring biological diversity: standard methods for ants. Smithsonian Institution Press, Washington, D.C.

Andersen, A. N. 1990. The use of ant communities to evaluate change in Australian terrestrial ecosystems: a review and a recipe. Proceedings of the Ecological Society of Australia 16:347-357.

Beier, P., and R. F. Noss. 1998. Do habitat corridors provide connectivity? Conservation Biology 12:1241-1252.

Bierregaard, R. O., Jr., T. E. Lovejoy, V. Kapos, A. A. dos Santos, and R. W. Hutchings. 1992. The biological dynamics of tropical rain forest fragments. Biosciencezzz 42:859-866.

Brown, J. H., and A. Kodric-Brown. 1977. Turnover rates in insular biogeography. Ecology 58:445-449.

Burnham, K. P., and W. S. Overton. 1979. Robust estimation of population size when capture probabilities vary among animals. Ecology 60:927-936

Cantrell, R. S., C. Cosner, and W. F. Fagan. 1998. Competitive reversals inside ecological reserves: the role of external habitat degradation. Journal of Mathematical Biology 37:491-533.

Colwell, R. K., and J. A. Coddington. 1994. Estimating terrestrial biodiversity through extrapolation. Philosophical Transactions of the Royal Society of London Series B 345:101-118.

Crome, H. J. 1997. Researching tropical forest fragmentation: shall we keep on doing what we are doing? Pages 485-501 in W. F. Laurance and R. O. Bierregaard, editors. Tropical forest remnants: ecology, management, and conservation of tropical forest fragments. The University of Chicago Press, Chicago.

Franklin, J. F. 1993. Preserving biodiversity: species, ecosystems or landscapes? Ecological Applications 3:202-205.

Franks, N. R., and W. H. Bossert. 1983. The influence of swarm-raiding army ants on the patchiness and diversity of a tropical leaf-litter ant community. Pages $151-163$ in S. L. Sutton, D. C. Whitmore, and A. C. Chadwick, editors. Tropical rain forest: ecology and management. Blackwell, Oxford, United Kingdom.
Greenberg, R., P. Bichier, A. Cruz Angon, and R. Reitsma. 1997a. Bird populations in shade and sun coffee plantations in central Guatemala. Conservation Biology 11:448-459.

Greenberg, R., P. Bichier, and J. Sterling. 1997b. Bird populations in rustic and shade coffee plantations of eastern Chiapas, Mexico. Biotropica 29:501-514.

Gustafson, R. J., and R. H. Gardner. 1996. The effect of landscape heterogeneity on the probability of patch colonization. Ecology 77 : 94-107.

Hanski, I. 1985. Single-species spatial dynamics may contribute to long term rarity and commonness. Ecology 66:335-343.

Hanski, I. 1991. Single-species metapopulation dynamics: concept, models and observations. Biological Journal of the Linnean Society 42:17-38.

Hansson, L. 1991. Dispersal and connectivity in metapopulations. Biological Journal of the Linnean Society 42:89-103.

Harris, L. D., and J. Scheck. 1991. From implications to applications: the dispersal corridor principle applied to the conservation of biological diversity. Pages 189-220 in D. A. Sounders and R. J. Hobbs, editors. Nature conservation 2: the role of corridors. Surrey Beatty, Sydney.

Hobbs, R. J. 1992. The role of corridors in conservation: solution or bandwagon? Trends in Ecology and Evolution 7:389-392.

Hölldobler, B., and E. O. Wilson. 1990. The ants. Belknap Press of Harvard University Press, Cambridge, Massachusetts.

Jules, E. 1997. History and biological consequences of forest fragmentation: a study of Trillium ovatus in Southwestern Oregon. Ph.D. dissertation. University of Michigan, Ann Arbor.

Laurance, W. F. 1991. Ecological correlates of extinction proneness in Australian tropical rainforest mammals. Conservation Biology 5:79-89.

Laurance, W. F. and R. O. Bierregaard, editors. 1997. Tropical forest remnants: ecology, management, and conservation of tropical forest fragments. The University of Chicago Press, Chicago.

Levings, S. C. 1983. Seasonal, annual, and among-site variation in the ground ant community of a deciduous tropical forest: some causes of patchy species distributions. Ecological Monographs 53:435-455.

Levins, R. 1969. Some demographic and genetic consequences of environmental heterogeneity for biological control. Bulletin of the Entomological Society of America 15: 237-240.

Majer, J. D. 1983. Ants: bioindicators of mine site rehabilitation, land use and land conservation. Environmental Management 7:375-383.

Moguel, P., and V. M. Toledo. 1999. Biodiversity conservation in traditional coffee systems of Mexico. Conservation Biology 13:1-12.

Noss, R. F. 1987. Corridors in real landscapes: a reply to Simberloff and Cox. Conservation Biology 1:159-164.

Perfecto, I. 1991. Dynamics of Solenopsis geminata in a tropical fallow field after ploughing. Oikos 62:139-144.

Perfecto, I. 1994. Foraging behavior as a determinant of asymmetric competitive interactions between two ant species in a tropical agroecosystem. Oecologia 98:184-192.

Perfecto, I., and R. Snelling. 1995. Biodiversity and tropical ecosystem transformation: ant diversity in the coffee agroecosystem in Costa Rica. Ecological Applications 5:1084-1097.

Perfecto, I., and J. H. Vandermeer. 1994. Understanding biodiversity loss in agroecosystems: reduction of ant diversity resulting from transformation of the coffee ecosystem in Costa Rica. Entomology (Trends in Agricultural Sciences) 2:7-13.

Perfecto, I., R. Rice, R. Greenberg, and M. Van der Voolt. 1996. Shade coffee as refuge of biodiversity. BioScience 46:598-608.

Perfecto, I., J. Vandermeer, P. Hansen, and V. Cartín. 1997. Arthropod biodiversity loss and the transformation of a tropical agro-ecosystem. Biodiversity and Conservation 6:935-945 .

Read, J. J. 1996. Use of ants to monitor environmental impacts of salt spray from a mine in arid Australia. Biodiversity and Conservation 5:1533-1543.

Rice, R. A. 1997. The land use patterns and the history of coffee in eastern Chiapas, Mexico. Agriculture and Human Values 14:127-143. 
Simberloff, D. F., and J. Cox, 1987. Consequences and cost of conservation corridors. Conservation Biology 1:63-71.

Soulé, M. E., and M. E. Gilpin. 1991. The theory of wildlife corridor capability. Pages 3-8 in D. A. Sounders and R. J. Hobbs, editors. Nature conservation 2: the role of corridors. Surrey Beatty, Sydney.

Stout, R. J., and J. H. Vandermeer. 1975. Comparison of species richness for stream-inhabiting insects in tropical and mid-latitude streams. The American Naturalist 100:263-280.

Tocher, M. D., C. Gascon, and B. L. Zimmerman. 1997. Fragmentation effects on a central Amazonian frog community: a ten year study.
Pages 124-137 in W. F. Laurance and R. O. Bierregaard, editors. Tropical forest remnants: ecology, management, and conservation of tropical forest fragments. The University of Chicago Press, Chicago.

Vandermeer, J., and I. Perfecto. 1997. The agroecosystem: a need for the conservation biologist's lens. Conservation Biology 11:1-3.

Weins, J. A., N. C. Stenseth, B. Van Horne, and R. A. Ims. 1995. Ecological mechanisms and landscape ecology. Oikos 66:369-380.

White, G. C., K. P. Burnham, D. L. Otis, and D. R. Anderson. 1978. User's manual for program CAPTURE. Utah State University Press, Logan.

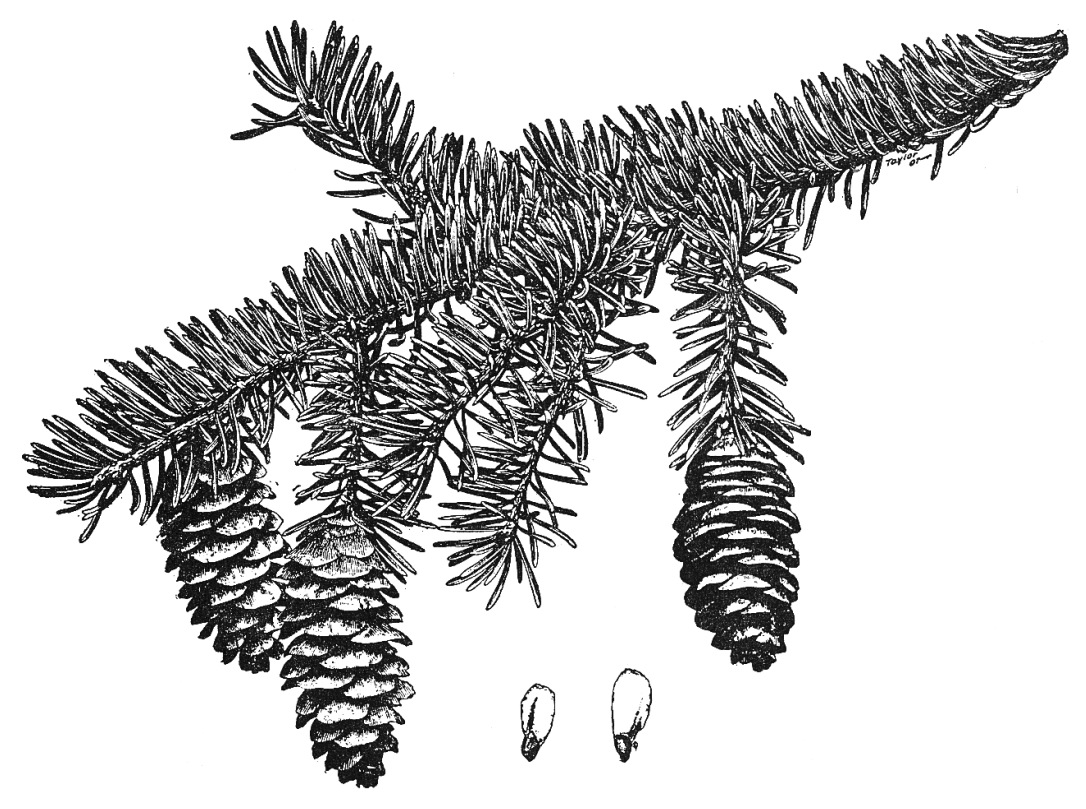

